\title{
UJI TERATOGENITAS EKSTRAK ETANOL 70\% DAUN KELOR (Moringa oleifera Lam.) TERHADAP MENCIT PUTIH BUNTING HIPERGLIKEMIA
}

\section{TERATOGENICITY OF MORINGA LEAVES ETHANOLIC EXTRACT IN HYPERGLICEMIA PREGNANT MICE}

\author{
Rindita', Kriana Efendi', Tiska Dwi Armelia ${ }^{3}$ \\ ${ }^{1}$ Unit Bidang IImu Biologi Farmasi, Program Studi Farmasi, Fakultas Farmasi dan Sains, Universitas \\ Muhammadiyah Prof. DR. HAMKA, Jakarta \\ ${ }^{2}$ Unit Bidang IImu Farmakologi, Program Studi Farmasi, Fakultas Farmasi dan Sains, Universitas \\ Muhammadiyah Prof. DR. HAMKA, Jakarta \\ ${ }^{3}$ Program Studi Pendidikan Apoteker, Fakultas Farmasi dan Sains, Universitas Muhammadiyah \\ Prof. DR. HAMKA, Jakarta
}

Naskah diterima tanggal 24 Juni 2020

\begin{abstract}
Diabetic during pregnancy may affect a fetus and cause abortion, disability, excessive baby weight, premature birth, and even death. Efforts needed to prevent bad effects on the fetus. This research was conducted to find out the effect of moringa leaves ethanolic extract to fetus development and to know the effectiveness in decreasing blood glucose content to hyperglycemia pregnant mice. This experimental research was used in a completely randomized design with 30 female mice, divided into 6 groups. All groups were induced with alloxan, except normal group. Normal and negative control groups only were given with $\mathrm{Na}$ CMC. As a comparison, $65 \mathrm{mg} / \mathrm{kg}$ b.w. metformin was used in the positive control group. The extract was administered orally on the day $6^{\text {th }}$ to $15^{\text {th }}$ of pregnancy, with 3 dosages variation: $300 \mathrm{mg} / \mathrm{kg}$ b.w., $600 \mathrm{mg} / \mathrm{kg}$ b.w., and $1200 \mathrm{mg} / \mathrm{kg}$ b.w. The mice were performed laparotomy on the day $18^{\text {th }}$ of pregnancy. The teratogenic effect was observed by the total fetus (alive, dead, resorption), fetus weight, long, and morphological disability. Based on the result, the extract does not show any teratogenic effect to the fetus development and able to reduce blood glucose content in hyperglycemia white mice with 50,50\%, 51,68\%, and 56,56\% respectively.
\end{abstract}

Keywords : hyperglycemia, moringa leaves extract, teratogenic effect

\begin{abstract}
ABSTRAK
Diabetes selama kehamilan merupakan kondisi yang sangat berpengaruh terhadap janin, di antaranya menyebabkan keguguran, kecacatan, berat badan bayi berlebih, lahir prematur, serta kematian. Maka perlu dilakukan pencegahan dampak buruk tersebut bagi janin. Tujuan penelitian ini adalah untuk mengetahui pengaruh pemberian ekstrak etanol $70 \%$ daun kelor terhadap perkembangan fetus serta mengetahui efektivitasnya dalam menurunkan kadar glukosa darah pada mencit putih bunting hiperglikemia. Penelitian ini menggunakan metode eksperimen dengan desain Rancangan Acak Lengkap (RAL), menggunakan 30 ekor mencit betina yang dibagi menjadi 6 kelompok. Seluruh kelompok diinduksi aloksan kecuali kelompok kontrol normal. Kelompok kontrol normal dan kontrol negatif hanya diberi $\mathrm{Na}-\mathrm{CMC}$. Sebagai bahan pembanding digunakan metformin dengan dosis $65 \mathrm{mg} / \mathrm{KgBB}$ pada ke!ompok kontrol positif. Sediaan ekstrak diberikan secara oral pada hari ke-6 hingga ke-15 kehamilan dengan 3 variasi dosis, yaitu: dosis $300 \mathrm{mg} / \mathrm{KgBB}, 600 \mathrm{mg} / \mathrm{KgBB}$, dan $1200 \mathrm{mg} / \mathrm{KgBB}$. Mencit dilaparatomi pada hari ke-18 kehamilan. Efek teratogenik dilihat dari jumlah fetus (hidup, mati, dan resorpsi), berat, panjang, dan kelainan morfologi. Berdasarkan hasil penelitian, ekstrak etanol $70 \%$ daun kelor tidak menimbulkan kecacatan pada fetus yang dilahirkan, serta mampu menurunkan kadar glukosa darah mencit sebesar 50,50\%, 51,68\%, dan 56,56\% berturut-turut pada mencit putih (Mus musculus) bunting hiperglikemia.
\end{abstract}

Kata kunci: ekstrak daun kelor, hiperglikemia, teratogenitas 


\section{PENDAHULUAN}

Selama kehamilan, ibu dapat mengalami suatu keluhan yang membutuhkan obat dan membuat kehamilan menjadi beresiko tinggi. Misalnya terjadi peningkatan kadar glukosa dalam darah yang mengakibatkan diabetes melitus. Kondisi tersebut sangat berpengaruh terhadap janin, seperti keguguran, kecacatan, berat badan bayi berlebih, kelebihan cairan ketuban, lahir prematur, serta kematian. Diabetes selama kehamilan terbagi menjadi dua, yaitu diabetes gestasional (selama kehamilan) dan diabetes pragestasional (sebelum kehamilan) (Leveno, 2015).

Diabetes pragestasional dapat berupa diabetes tipe I dan tipe II dan dapat terus berlanjut hingga setelah masa hamil. Diabetes ini memiliki dampak yang sigifikan terhadap janin yang dilahirkan (Leveno, 2015). Oleh karena itu, perlu dilakukan upaya untuk mengatasi kondisi tersebut guna mencegah dampak buruk bagi janin yang akan dilahirkan.

Salah satu upaya yang dapat dilakukan guna mengatasi kondisi tersebut adalah dengan menggunakan obat antidiabetes seperti insulin. Namun, umumnya insulin menimbulkan efek hipoglikemia (Dipiro et al., 2015), penggunaannya rumit, dan harganya cukup mahal (Maelaiti, 2013). Oleh karena itu, perlu alternatif lain untuk meminimalisir efek tersebut, misalnya menggunakan obat herbal. Salah satu tanaman obat yang telah diteliti khasiatnya dalam menurunkan kadar glukosa darah adalah daun kelor (Moringa oleifera Lam.).

Tanaman kelor (Moringa oleifera) secara tradisional banyak digunakan sebagai bahan makanan dan obat, mulai dari bagian daun, biji, batang, getah, akar, dan bunganya. Akan tetapi, ekstrak daunnya yang diketahui memiliki aktivitas antioksidan yang tinggi, juga efek antidiabetes (Stohs \& Hartman 2015). Tanaman ini berasal dari India dan telah tersebar luas ke seluruh wilayah tropis dan subtropis di seluruh dunia, banyak digunakan sebagai obat alternatif termasuk oleh masyarakat yang tinggal terpencil jauh dari fasilitas kesehatan (Brilhante et al., 2017).

Ekstrak air dan etanol dari daun kelor mengandung flavonoid, antrakuinon, alkaloid, saponin, steroid, terpenoid glikosida jantung, antosianin, tanin, dan karotenoid (Nweze et al., 2014). Puspasari (2016) juga membuktikan bahwa ekstrak etanol $70 \%$ daun kelor memiliki aktivitas menghambat kerja enzim -glukosidase, menyebabkan penurunan laju pencernaan karbohidrat menjadi monosakarida yang dapat diserap oleh usus halus, sehingga menurunkan kadar glukosa darah (Dipiro et al., 2008).

Selama kehamilan, ibu dan janin adalah unit fungsi yang tak terpisahkan. Obat yang melintasi plasenta mengalami proses biotransformasi menjadi teratogen (Depkes RI, 2006). Maka diperlukan pertimbangan khusus, karena telah terbukti beberapa obat tradisional tertentu seperti ekstrak etanol daun alpukat memiliki efek samping teratogenik pada fetus (Ong, 2013). Oleh karena itu, perlu dilakukan penelitian uji teratogenitas ekstrak etanol $70 \%$ daun kelor (Moringa oleifera) terhadap mencit bunting hiperglikemia.

\section{METODE PENELITIAN Alat}

Alat-alat yang digunakan adalah peralatan gelas laboratorium (Pyrex), kandang mencit, wadah maserasi, sonde oral (Obsidi medica), spuit, timbangan hewan, timbangan analitik (Ohaus pioneer), vacuum rotary evaporator (Eyela), oven (Memmert universal), waterbath, Karl Fischer, alat bedah, glucometer (Easy Touch), lumpang dan alu.

\section{Bahan}

Bahan yang digunakan antara lain simplisia daun kelor (Moringa oleifera Lam.) (BALITTRO), akuades, larutan etanol $70 \%$, etanol $95 \%$, karbon aktif, serbuk $\mathrm{Mg}, \mathrm{FeCl}_{3}$, kloroform, asam asetat anhidrat, $\mathrm{H}_{2} \mathrm{SO}_{4}$, pereaksi Bouchardat, pereaksi Mayer, pereaksi Dragendorff, $\mathrm{HCl}$, ketamin, larutan bouin (formaldehid 14\%, asam asetat glasial, asam pikrat jenuh), $\mathrm{Na}$ CMC, aloksan/alloxan monohydrate (Sigma-Aldrich, Switzerland), metformin/metformin hydrochloride $B P$ (Sohan Healthcare, Pune), pakan dan minum mencit.

Hewan yang digunakan adalah mencit (Mus musculus) betina galur Swiss webster yang berumur 2-3 bulan dengan berat badan 20-30 gram, yang diperoleh dari peternakan hewan (mencit) Cibinong-Bogor.

\section{Metode}

\section{Determinasi Tanaman}

Daun kelor dideterminasi di Herbarium Bogoriense, Bidang Pusat Penelitian Biologi LIPI Cibinong untuk memastikan kebenaran tanaman yang digunakan.

\section{Pembuatan Ekstrak Etanol Daun Kelor}

Sebanyak $700 \mathrm{~g}$ serbuk daun kelor dimaserasi dengan etanol $70 \%$ sebanyak $7 \mathrm{~L}$ dan diaduk tiap 6 jam. Maserat dipekatkan menggunakan vacuum rotary evaporator lalu diuapkan di waterbath pada suhu $50^{\circ} \mathrm{C}$ hingga didapatkan ekstrak kental (Depkes RI 2008).

\section{Pemeriksaan Karakteristik Ekstrak Etanol $70 \%$ Daun Kelor \\ a. Pemeriksaan Organoleptik \\ Pemeriksaan organoleptik meliputi} pemeriksaan bentuk, warna, bau, dan rasa dari simplisia dan ekstrak etanol $70 \%$ daun kelor. 
b. Perhitungan Rendemen

Perhitungan rendemen dilakukan menggunakan rumus (Depkes RI 2008):

$$
\% \text { Rendemen }=\frac{\text { Berat ekstrak }}{\text { Berat serbuk simplisia }} \times 100 \%
$$

\section{c. Penetapan Susut Pengeringan}

Sebanyak $1 \mathrm{~g}$ ekstrak kental dimasukkan ke dalam botol timbang tertutup, kemudian dimasukkan ke dalam oven suhu $105^{\circ} \mathrm{C}$ hingga bobot tetap. Pada waktu oven dibuka, botol segera ditutup dan dibiarkan dalam eksikator sampai suhu mencapai suhu ruang (Depkes RI 2008).

\section{Penapisan Fitokimia}

Penapisan fitokimia dilakukan melalui uji kandungan alkaloid, flavonoid, tanin, saponin, terpenoid, dan steroid (Tabel 1).

\section{Persiapan Hewan Uji}

Penelitian ini menggunakan 6 kelompok hewan uji dengan masing-masing kelompok terdiri dari 5 ekor. Penggunaan hewan uji sesuai hasil persetujuan komite etik dengan Nomor (Ethical Approval) 02/18.09/047.

\section{Pemberian Induksi}

Penginduksi aloksan yang digunakan dengan dosis $120 \mathrm{mg} / \mathrm{KgBB}$ diberikan secara intraperitoneal setelah hewan diaklimatisasi selama 10 hari. Aloksan sebanyak $120 \mathrm{mg}$ dilarutkan dengan larutan fisiologis $\mathrm{NaCl} 0,9 \%$ ad $25 \mathrm{~mL}$.

\section{Pemberian Zat Pembanding}

Pembanding yang digunakan adalah Metformin dengan dosis $102,75 \mathrm{mg} / \mathrm{KgBB}$. Metformin ditimbang berdasarkan dosis yang telah ditentukan, kemudian disuspensikan dengan $\mathrm{Na} \mathrm{CMC}$ 0,5\%. Larutan zat pembanding diberikan secara oral.

\section{Pemberian Zat Uji}

Berdasarkan penelitian sebelumnya, ekstrak etanol $70 \%$ daun kelor dapat menurunkan kadar glukosa darah pada tikus jantan pada dosis $150 \mathrm{mg} / \mathrm{KgBB}$ (Fatahillah, 2013), kemudian dikonversikan ke dosis mencit menjadi $300 \mathrm{mg} / \mathrm{KgBB}$. Dosis yang digunakan dalam penelitian ini adalah variasi 3 dosis yaitu dosis $300 \mathrm{mg} / \mathrm{KgBB}, 600 \mathrm{mg} / \mathrm{KgBB}$, dan 1200 $\mathrm{mg} / \mathrm{KgBB}$. Ekstrak ditimbang berdasarkan dosis yang telah ditentukan, kemudian disuspensikan dengan $\mathrm{Na} \mathrm{CMC}$ 0,5\%. Larutan uji diberikan secara oral selama masa organogenesis.

\section{Pemeriksaan Darah Hewan Uji}

Pengukuran kadar glukosa darah pada induk mencit dilakukan pada hari ke-3 setelah induksi, hari ke-15 (hari ke-6 kehamilan), dan hari ke-25 (hari ke-16 kehamilan).

\section{Penentuan Siklus Estrus pada Mencit Betina}

Penentuan siklus estrus dilakukan secara visual dengan mengamati secara langsung vagina mencit (Almahdy, 2012).

\section{Mengawinkan Hewan Percobaan}

Pengawinan dilakukan dengan menyatukan 4 ekor mencit betina dengan 1 ekor mencit jantan dalam satu kandang pada sore hari. Keesokan paginya dilakukan pengamatan di daerah vagina, jika ditemukan sumbat vagina (vaginal plug), maka mencit dinyatakan telah kawin dan dihitung sebagai hari ke-0 dari kehamilan (Almahdy, 2012).

\section{Alokasi Hewan Uji}

Hewan uji yang terbukti bunting dipelihara dalam kandang individual dan dikelompokkan secara acak menjadi 6 kelompok seperti pada Tabel 2.

\section{Laparatomi}

Laparatomi dilakukan pada hari ke-18. Sebelumnya, induk mencit ditimbang dan dibius dengan ketamin dosis 2,47 mg/20 gBB secara intra muscular kemudian dibedah untuk diambil fetusnya. Parameter yang diamati meliputi jumlah fetus yang hidup maupun yang mati, resorpsi, panjang dan berat fetus, serta ada tidaknya kecacatan pada fetus secara morfologis pada

\begin{tabular}{|c|c|c|c|}
\hline $\begin{array}{c}\text { Kandungan } \\
\text { Kimia }\end{array}$ & Pereaksi & Warna/Endapan & Pustaka \\
\hline \multirow[t]{3}{*}{ Alkaloid } & Mayer & Endapan putih atau kuning & Depkes 1995 \\
\hline & Dragendorff & $\begin{array}{l}\text { Endapan kuning, oranye, sampai } \\
\text { merah bata }\end{array}$ & Zulfiana 2017 \\
\hline & Bouchardat & Endapan cokelat sampai hitam & Depkes 1995 \\
\hline Flavonoid & Metanol $+\mathrm{HCL}_{(p)}+$ logam Mg & Larutan merah jingga & Depkes 1995 \\
\hline Tanin & Akuades $+\mathrm{FeCl}_{3}$ & Hijau kehitaman atau biru tua & Depkes 1995 \\
\hline Saponin & Akuades $+\mathrm{HCl}$ & Buih & Depkes 1995 \\
\hline Terpenoid & $\begin{array}{l}\text { Kloroform }+ \text { Asam asetat } \\
\text { anhidrat }+\mathrm{H}_{2} \mathrm{SO}_{4(\mathrm{p})}\end{array}$ & Cincin kecokelatan atau violet & $\begin{array}{l}\text { Hayati dan Halimah } \\
2010\end{array}$ \\
\hline Steroid & $\begin{array}{l}\text { Kloroform }+ \text { Asam asetat } \\
\text { anhidrat }+\mathrm{H}_{2} \mathrm{SO}_{4(\mathrm{p})}\end{array}$ & Warna hijau & $\begin{array}{l}\text { Hayati dan Halimah } \\
2010\end{array}$ \\
\hline
\end{tabular}

Tabel 1. Penapisan Fitokimia 
Tabel 2. Pengelompokan Hewan Uji

\begin{tabular}{ll}
\hline \multicolumn{1}{c}{ Kelompok } & \multicolumn{1}{c}{ Perlakuan } \\
\hline Kelompok I (kontrol normal) & Diberi suspensi Na CMC 0,5\% dan pakan serta minum \\
Kelompok II (kontrol negatif) & Diinduksi dengan al oksan $120 \mathrm{mg} / \mathrm{kgBB}$ \\
Kelompok III (kontrol positif) & Diinduksi dengan aloksan dan diberi suspensi metformin 102,75 \\
& mg/KgBB \\
Kelompok IV (dosis uji 1) & Diinduksi dengan aloksan dan diberi suspensi ekstrak etanol \\
& $70 \%$ daun kelor $300 \mathrm{mg} / \mathrm{KgBB}$ \\
Kelompok V (dosis uji 2) & Diinduksi dengan aloksan dan diberi suspensi ekstrak etanol \\
& $70 \%$ daun kelor 600 mg/KgBB \\
Kelompok VI (dosis uji 3) & Diinduksi dengan aloksan dan diberi suspensi ekstrak etanol \\
& $70 \%$ daun kelor $1200 \mathrm{mg} / \mathrm{KgBB}$ \\
\hline
\end{tabular}

kepala, telinga, ekor, kelopak mata, jari kaki depan-belakang.

14. Fiksasi

Setelah diamati secara visual, kemudian fetus difiksasi dengan larutan Bouin selama 14 hari, kemudian disayat. Pengamatan bagian visceral dilakukan terhadap bagian langit-langit mulut (Almahdy, 2012).

\section{Analisis Data}

Data yang dianalisis adalah data berat badan fetus dan data penurunan kadar glukosa darah induk. Bila data terdistribusi normal dan homogen, analisis dilanjutkan dengan menggunakan metode analisis varian satu arah (one way ANOVA). Bila hasil uji tersebut terdapat perbedaan yang signifikan $(\alpha<0,05)$, selanjutnya dilakukan uji Tukey untuk mengetahui adanya perbedaan antar kelompok.

\section{HASIL DAN PEMBAHASAN}

1. Hasil Determinasi Tanaman Kelor

Hasil dari determinasi menunjukkan bahwa tanaman yang digunakan dalam penelitian ini adalah tanaman kelor (Moringa oleifera Lam.) yang termasuk dalam suku Moringaceae.

\section{Hasil Ekstraksi Daun Kelor}

Dari $700 \mathrm{~g}$ serbuk daun kelor yang dimaserasi dengan pelarut etanol $70 \%$ diperoleh maserat sebanyak $5 \mathrm{~L}$. Maserat dipekatkan dengan vacuum rotary evaporator. Ekstrak kental yang didapatkan sebanyak 109,18 g.

\section{Hasil Uji Karakteristik Ekstrak Daun Kelor}

\section{a. Hasil Uji Organoleptik}

Hasil uji organoleptik ekstrak daun kelor menunjukkan ekstrak berbentuk kental, berbau khas, berasa pahit dan berwarna cokelat.

\section{b. Rendemen dan Susut Pengeringan}

Hasil nilai rendemen yang didapat adalah sebesar $15,60 \%$. Hasil susut pengeringan yang didapatkan sebesar 7,90\%. Hal ini menunjukkan bahwa jumlah senyawa yang hilang pada proses pengeringan hanya sebanyak $7,90 \%$.

\section{Penapisan Fitokimia}

Penapisan fitokimia memperoleh hasil bahwa ekstrak yang diperoleh positif mengandung semua senyawa yang diuji kecuali steroid (Tabel 3).

\section{Hasil Uji Teratogenitas Ekstrak Etanol \\ 70\% Daun Kelor Terhadap Fetus Mencit \\ Dari hasil pengamatan terhadap masing-} masing kelompok, tidak ditemukan adanya fetus mati maupun resorpsi. Hasil pengamatan pada

Tabel 3. Hasil Penapisan Fitokimia Ekstrak Etanol 70\% Daun Kelor

\begin{tabular}{llcl}
\hline $\begin{array}{c}\text { Kandungan } \\
\text { kimia }\end{array}$ & \multicolumn{1}{c}{ Pereaksi } & Hasil & \multicolumn{1}{c}{ Wama/Endapan } \\
\hline Alkaloid & Mayer & + & Endapan kuning \\
& Dragendorff & + & Endapan oranye \\
& Bouchardat & + & Endapan cokelat \\
Flavonoid & Metanol $+\mathrm{HCL}_{(\mathrm{p})}+$ logam $\mathrm{Mg}$ & + & Larutan merah \\
Tanin & Akuades $+\mathrm{FeCl}_{3}$ & + & Hitam kehijauan \\
Saponin & Akuades $+\mathrm{HCl}$ & + & Buih \\
Terpenoid & Kloroform + Asam asetat anhidrat $+\mathrm{H}_{2} \mathrm{SO}_{4(\mathrm{p})}$ & + & Cincin kecokelatan \\
Steroid & & - & Larutan cokelat \\
\hline
\end{tabular}

Keterangan $:+=$ Positif mengandung

$$
\text { - = Negatif mengandung }
$$




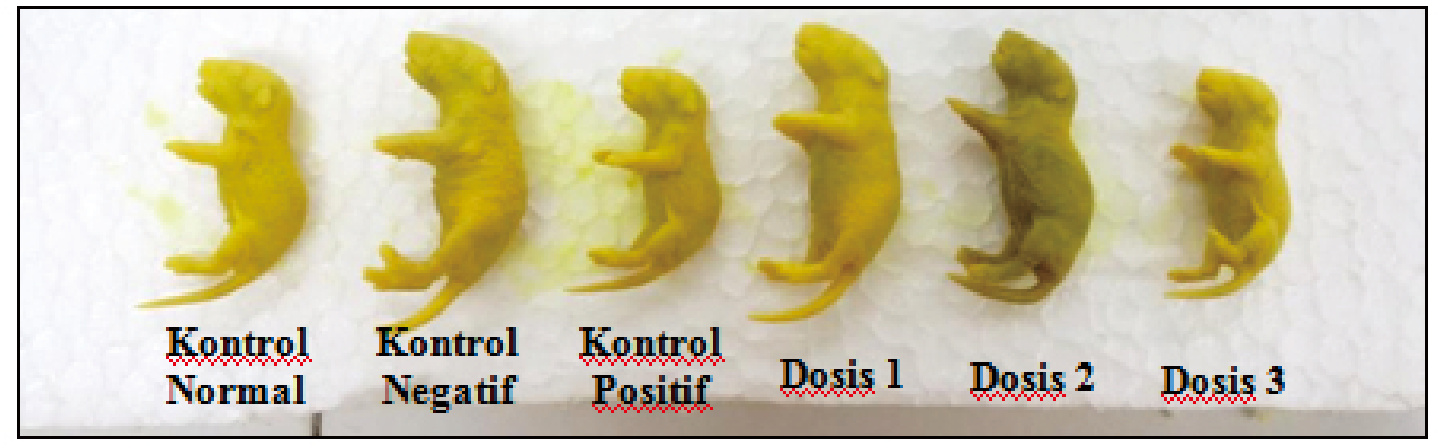

Gambar 1. Fetus Mencit dari Masing-masing Kelompok Perlakuan

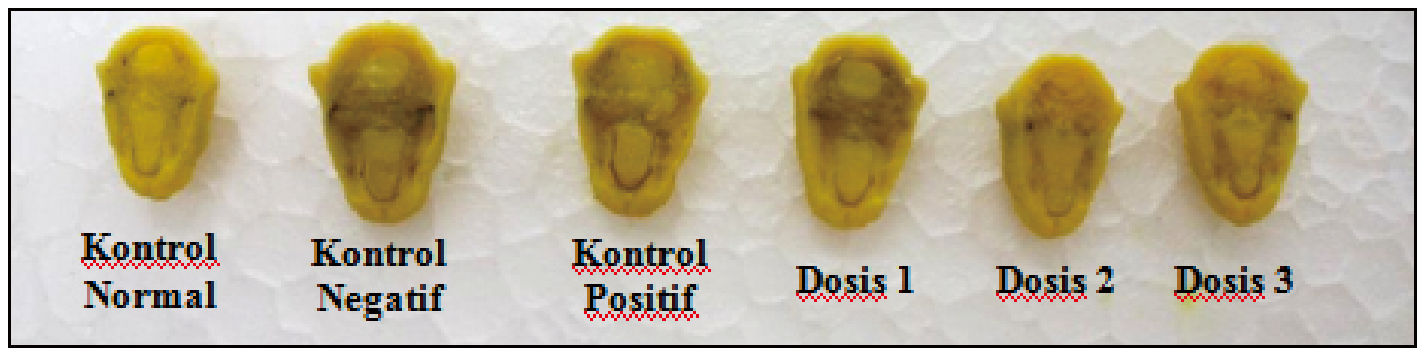

Gambar 2. Langit-langit Fetus Mencit dari Masing-masing Kelompok Perlakuan

kepala, daun telinga, kelopak mata, jari kaki depan-belakang, ekor (Gambar 1), dan langitlangit tidak ditemukan adanya kecacatan (Gambar 2), selain itu juga tidak ditemukan fetus yang mengalami tromboemboli. Hal ini menunjukkan bahwa pemberian ekstrak etanol $70 \%$ daun kelor tidak menyebabkan kecacatan pada fetus mencit dengan persentase kecacatan $0 \%$.

Selain itu, jumlah fetus, berat badan (Gambar 3) dan panjang badan fetus (Gambar 4) juga diamati. Dari masing-masing kelompok tidak ditemukan adanya fetus mati atau resorpsi.

Grafik menunjukkan bahwa fetus yang dihasilkan pada induk kelompok kontrol negatif mengalami peningkatan berat dan panjang badan. Hal ini menunjukkan bahwa induk hiperglikemia menghasilkan fetus dengan ukuran di atas normal.

\section{Hasil Pengukuran Kadar Glukosa Darah}

Hasil pengukuran kadar glukosa darah dapat dilihat pada Tabel 4 yang menunjukkan bahwa kadar glukosa darah tertinggi terdapat pada kelompok kontrol negatif yaitu sebesar $237,8 \mathrm{mg} / \mathrm{dL}$, kadar glukosa darah terendah terdapat pada kelompok kontrol normal yaitu sebesar 114,6 $\mathrm{mg} / \mathrm{dL}$, kelompok uji dosis 3 menghasilkan kadar glukosa darah sebesar $120,8 \mathrm{mg} / \mathrm{dl}$, hampir sama efektivitasnya dengan kelompok kontrol positif dalam menurunkan kadar glukosa darah. Kadar glukosa darah kelompok dosis 2 yaitu sebesar 116,6 mg/dL. Hasil pengukuran kadar glukosa darah menunjukkan bahwa ekstrak etanol $70 \%$ daun kelor dapat menurunkan kadar glukosa darah mencit bunting hiperglikemia.

\section{Analisis Data}

Hasil analisis data berat rata-rata fetus menggunakan ANOVA satu arah didapatkan nilai p $0,00 \leq a \quad 0,05$. Hal ini menunjukkan bahwa terdapat pengaruh perlakuan dan terdapat perbedaan dari keenam kelompok. Uji Tukey yang dilakukan menunjukkan adanya perbedaan antara kelompok kontrol normal dengan kelompok kontrol negatif, kelompok dosis 1, dan dosis 2. Hal ini berarti bahwa pemberian ekstrak

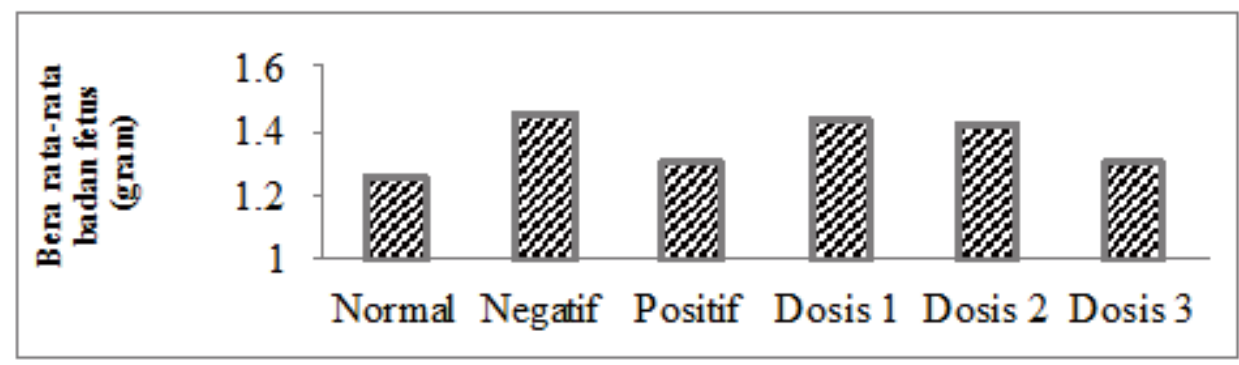

Gambar 3. Grafik Berat Badan Rata-rata Fetus Setelah Perlakuan 


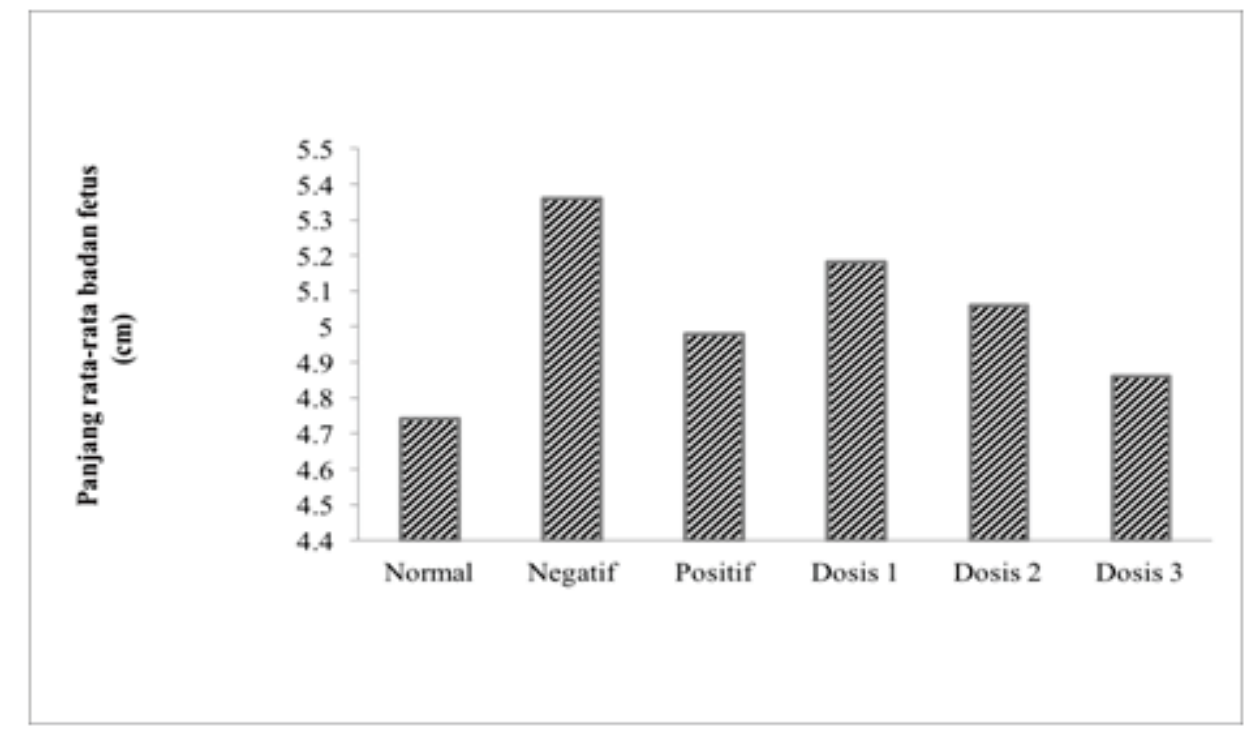

Gambar 4. Grafik Panjang Badan Rata-rata Fetus Setelah Perlakuan

Tabel 4 Hasil Pengukuran Rata-Rata Kadar Glukosa

\begin{tabular}{|c|c|c|c|c|}
\hline \multirow[t]{2}{*}{ Kelompok } & \multicolumn{3}{|c|}{ Glukosa Darah (mg/dl) } & \multirow[t]{2}{*}{$\%$ Penurunan } \\
\hline & Hari ke-3 & Hari ke-15 & Hari ke-25 & \\
\hline Normal & $\begin{array}{l}113,40 \\
(S D=12,60)\end{array}$ & $\begin{array}{l}119,40 \\
(S D=9,71)\end{array}$ & $\begin{array}{l}114,60 \\
(27,56)\end{array}$ & $\begin{array}{l}4,67 \\
(S D=19,16)\end{array}$ \\
\hline Negatif & $\begin{array}{l}311,40 \\
(S D=10,09)\end{array}$ & $\begin{array}{l}313,80 \\
(S D=9,63)\end{array}$ & $\begin{array}{l}237,80 \\
(S D=31,00)\end{array}$ & $\begin{array}{l}24,37 \\
(S D=7,86)\end{array}$ \\
\hline Positif & $\begin{array}{l}289,40 \\
(S D=9,07)\end{array}$ & $\begin{array}{l}291,60 \\
(S D=7,96)\end{array}$ & $\begin{array}{l}116,60 \\
(S D=24,14)\end{array}$ & $\begin{array}{l}60,01 \\
(S D=8,11)\end{array}$ \\
\hline Dosis 1 & $\begin{array}{l}288,40 \\
(S D=16,33)\end{array}$ & $\begin{array}{l}290,20 \\
(S D=16,41)\end{array}$ & $\begin{array}{l}144,80 \\
(S D=39,76)\end{array}$ & $\begin{array}{l}50,50 \\
(S D=11,18)\end{array}$ \\
\hline Dosis 2 & $\begin{array}{l}287,80 \\
(S D=25,11)\end{array}$ & $\begin{array}{l}291,60 \\
(S D=25,60)\end{array}$ & $\begin{array}{l}143,20 \\
(S D=46,79)\end{array}$ & $\begin{array}{l}51,68 \\
(S D=11,67)\end{array}$ \\
\hline Dosis 3 & $\begin{array}{l}274,40 \\
(S D=10,24)\end{array}$ & $\begin{array}{l}277,00 \\
(S D=11,27)\end{array}$ & $\begin{array}{l}120,80 \\
(S D=26,05)\end{array}$ & $\begin{array}{l}56,54 \\
(S D=8,08)\end{array}$ \\
\hline
\end{tabular}

etanol $70 \%$ daun kelor tidak menyebabkan teratogenik namun dapat menurunkan berat fetus dari induk mencit hiperglikemia. Hal ini sesuai dengan teori yang mengatakan bahwa bayi yang dilahirkan dari ibu yang mengalami diabetes pertumbuhannya meningkat (Leveno, 2015).

Berdasarkan hasil analisis data kadar glukosa darah mencit menggunakan ANOVA satu arah didapatkan nilai $p 0,00 \leq \alpha 0,05$. Hal ini menunjukkan bahwa terdapat pengaruh perlakuan dan terdapat perbedaan antar kelompok sehingga dilanjutkan uji Tukey untuk mengetahui ada tidaknya perbedaan yang bermakna antar kelompok. Dari uji Tukey didapatkan perbedaan antara kelompok normal dengan semua kelompok kecuali kelompok negatif. Hal ini menunjukkan bahwa pemberian ekstrak etanol $70 \%$ daun kelor dapat menurunkan kadar glukosa darah pada mencit bunting hiperglikemia.

Dengan demikian, dapat dinyatakan bahwa daun kelor aman dikonsumsi bagi ibu hamil. Hal ini sejalan dengan beberapa penelitian menggunakan hewan uji yang membuktikan bahwa ekstrak dan serbuk daun kelor menunjukkan derajat keamanan yang tinggi (Stohs \& Hartman, 2015). Dilihat dari segi ekonomi, kelor merupakan tanaman yang murah, ramah lingkungan, dan mudah diaplikasikan oleh kalangan masyarakat bahkan suku yang terpecil sekalipun (Brilhante et al., 2017).

\section{KESIMPULAN}

Berdasarkan penelitian yang telah dilakukan, ekstrak etanol $70 \%$ daun kelor pada dosis $300 \mathrm{mg} / \mathrm{KgBB}, 600 \mathrm{mg} / \mathrm{KgBB}$, dan 1200 $\mathrm{mg} / \mathrm{KgBB}$ mampu menurunkan kadar glukosa darah sebesar $50,50 \%, 51,68 \%$, dan $56,56 \%$ berturut-turut dan tidak menimbulkan efek teratogenik pada mencit putih bunting hiperglikemia.

\section{DAFTAR PUSTAKA}

Almahdy. 2012. Teratologi Eksperimental. Andalas University Press, Padang. HIm. 3-8, 10-11, 17-18, 55.

Brilhante R.S.N., Sales J.A., Pereira V.S., Castelo-Branco D.S.C.M., Cordeiro R.A., 
Sampaio C.M.S., Paiva M.A.N., Santos J.B.F., Sidrim J.J.C., Rocha M.F.G. 2017. Research advances on multiple uses of Moringa oleifera: A sustainable alternative for socially neglected population. Asian Pacific Journal of Tropical Medicine. 10 (7): 621-630.

Departemen Kesehatan RI. 1995. Materia Medika Indonesia. Jilid VI. Jakarta: Departemen Kesehatan. HIm. X, 324, 326, 333, 336-337.

Departemen Kesehatan RI. 2006. Pedoman Pelayanan Farmasi untuk Ibu Hamil dan Menyusui. Jakarta: Direktorat Jenderal Bina Kefarmasian dan Alat Kesehatan, HIm. 1.

Departemen Kesehatan RI. 2008. Farmakope Herbal Indonesia. Jilid I. Jakarta: Direktorat Jendral Pengawasan Obat dan Makanan, HIm. 171, 174-175.

Dipiro J.T., Chisholm-Burns M.A., Wells B.G., Schwinghammer T.L., Malone P.M., Kolesar J.M., Rotschafer J.C.. 2008. Pharmacotherapy Principle and Practice. The McGraw-Hill Companies. Amerika. HIm. 644, 650-653, 657.

Dipiro J.T., Wells B.G., Schwinghammer T.L., Dipiro C.V.. 2015. Pharmacotherapy Handbook. Ninth Edition. The McGrawHill Companies. Amerika. HIm. 161, 164166.

Fatahillah M. 2013. Uji Aktivitas Ekstrak Etanol 70 \% Daun Kelor (Moringa oleifera Lam.) sebagai Penurun Glukosa Darah pada Tikus Hipertrigliseridemia yang Diinduksi Aloksan. Jurnal Farmasains.

Hayati E.K., Halimah N. 2010. Phytochemical Test and Brine Shrimp Lethality Test Against Artemia salina Leach of AntingAnting (Acalypha indica Linn.) Plant Extract. Jurnal ALCHEMY. 1(2): 53-103.

Leveno K.J. 2015. Manual Komplikasi Kehamilan Williams. Terjemahan: Herman Octavius Ong, dkk. Edisi 23. EGC. Jakarta. HIm. 65, 479.

Maelaiti W.P. 2013. Manfaat dan Hambatan Terapi Insulin Menurut Perspektif Penderita Diabetes Melitus Tipe 2 yang Menggunakan Insulin di Poliklinik Penyakit Dalam RSUD Arifin Achmad Provinsi Riau. Skripsi. Universitas Riau, Riau.

Nweze N.O., Nwafor F.I. 2014. Phytochemichal, proximal and mineral composition of leaf extracts of Moringa oleifera Lam. From Nsukka, South-Eastern Nigeria. IOSR Journal of Pharmacy and Biological Sciences. 9 (1): 99-103.

Ong A.K. 2013. Uji Teratogenik Ekstrak Etanol Daun Alpukat (Persea americana Mill) pada Mencit Betina (Mus musculus). Jurnal IImiah Manusia Universitas Surabaya. 2(1):1-15.

Puspasari D. 2016. Aktivitas Inhibisi Enzim aGlukosidase Ekstrak Etanol 70\% Daun Kelor (Moringa oleifera Lam.). Skripsi. UHAMKA, Jakarta.

Stohs S.J., Hartman M. J. 2015. Review of The Safety and Efficacy of Moringa oleifera. Phytotherapy Research. 29: 796 - 804

Zulfiana E., Rahman N., Supriadi. 2017. Pengaruh Pemberian Ekstrak Buah Kelor (Moringa oleifera) Terhadap Penurunan Kadar Kolesterol Pada Darah Hewan Mencit (Mus musculus). Jurnal Akademika Kimia. FKIP Universitas Tadulako, Palu. 6(1):15-20. 